بهبود اندامزايى شاخساره نابهجا و تشكيل يينه از ريزنمونهاى برى اطلسى دورگه (Petunia hybrida L.)

\author{
فرزاد نظرى

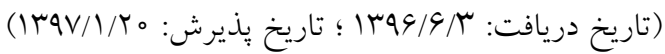

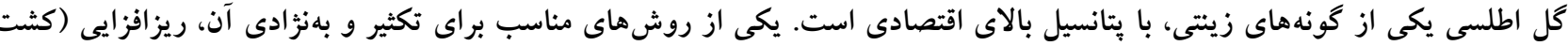

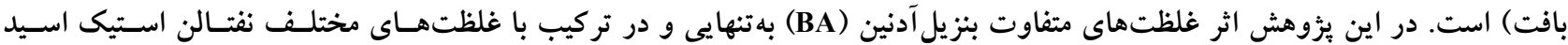

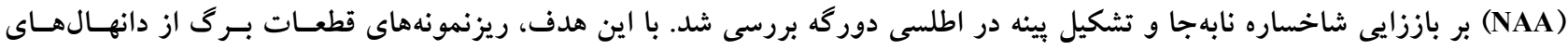
درونشيشهاى، روى محيط كشت موراشيخى و اسكو

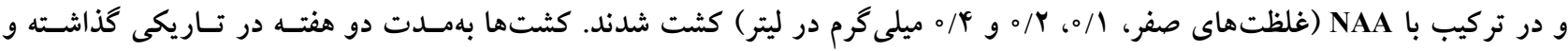

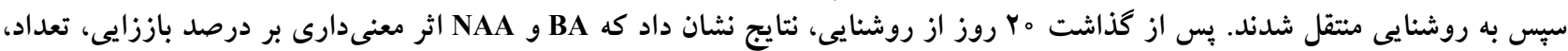

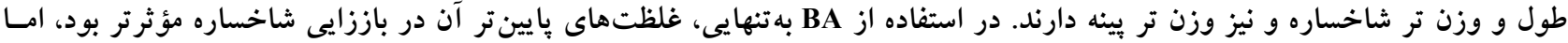

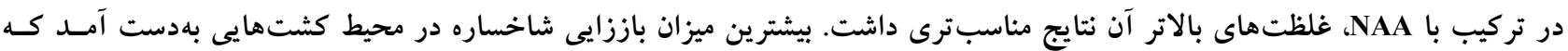

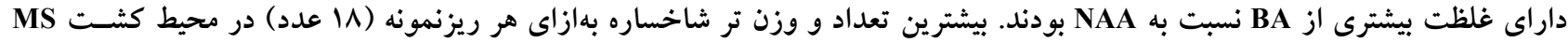

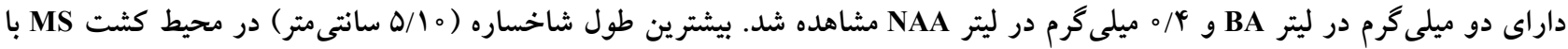

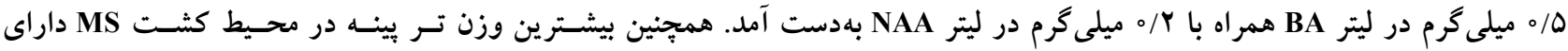

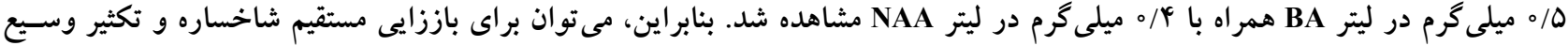
اطلسى از ريزنمونه هاى برك، محيط كشت MS داراى ب ميلى

وازههاى كليدى: اطلسى، انخيزش، باززايى مستقيم شاخساره، وينه، نسبت سايتوكينين به اكسين 
ريزنمونههاى شاخساره استفاده شود، بــراى پـــرآورى شاخسـاره

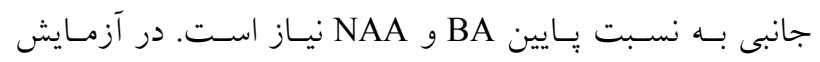
ديخرى بيشترين درصد باززايى (هأ درصــ) و بيشـترين تعسداد

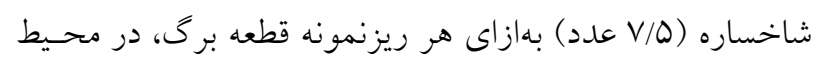

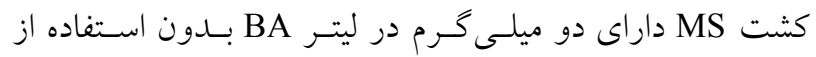

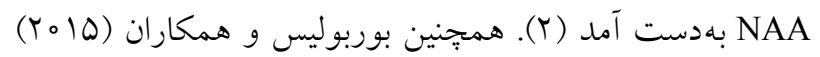

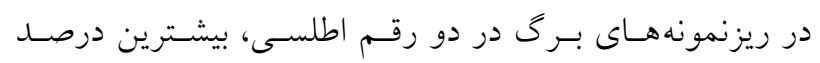

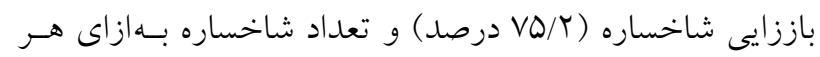

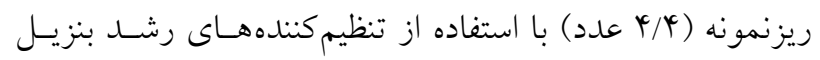

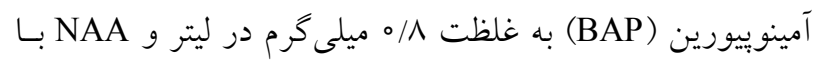

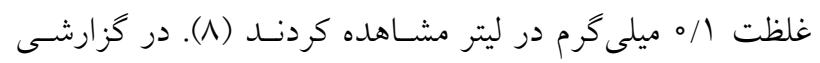

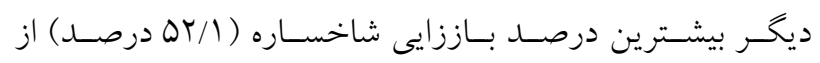

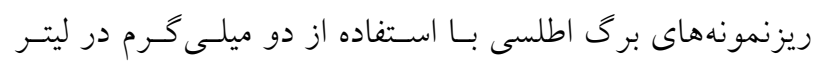

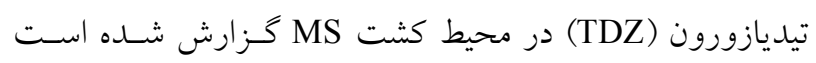

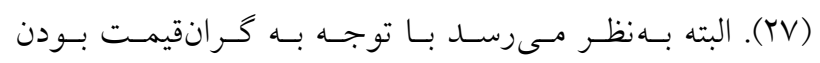

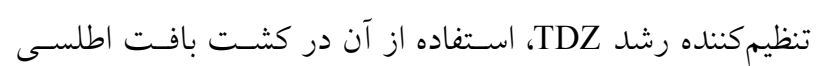

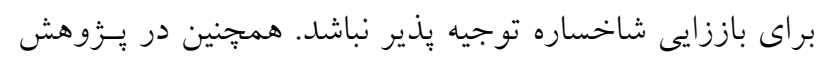

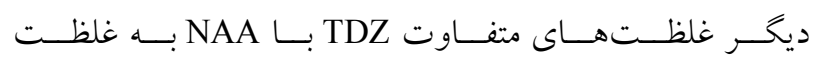

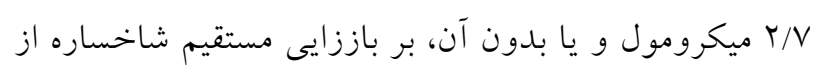

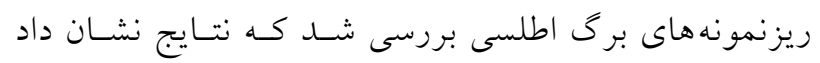

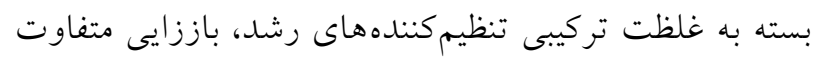

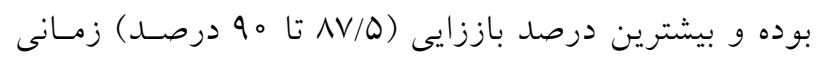

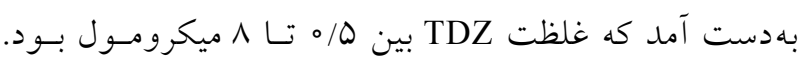

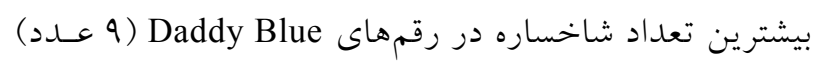

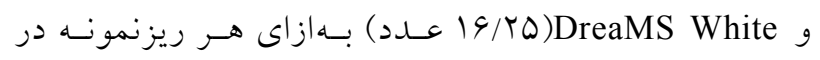
محيط كشت MS داراى جهار ميكرومول TDZ بدون كاربرد

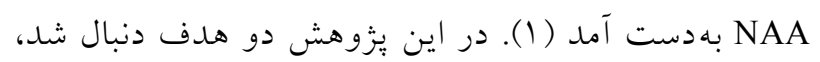

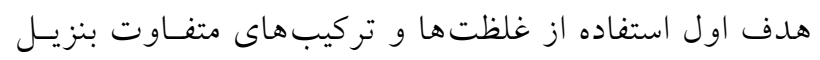

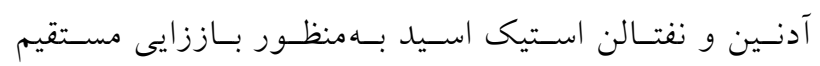

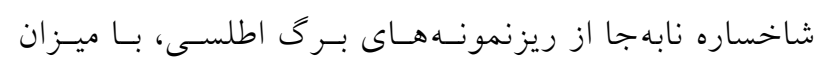

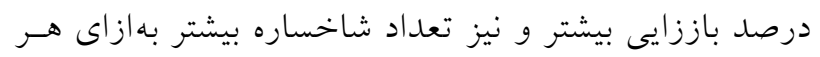

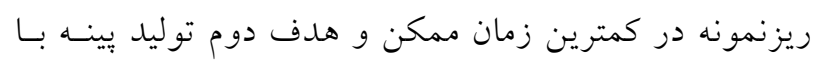

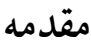

كل اطلسى از تيـره سـيبزمينسىسـانان (Solanaceae) در دهـــ

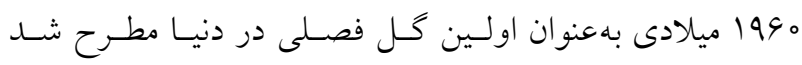

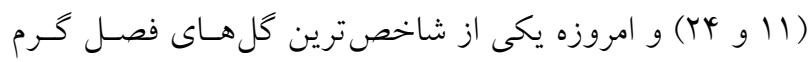
با تنوع رنخ زياد و كاربردهاى متفاوت است، كه هميشـه ارقـام

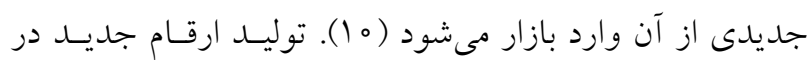

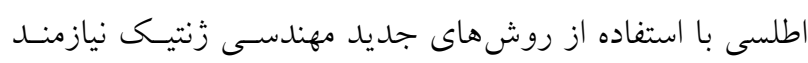

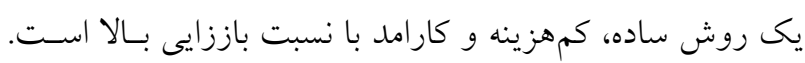

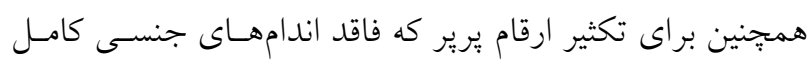
براى تشكيل بذر هستند، يك روش مناسب ريزافزايى و بهويـزئه

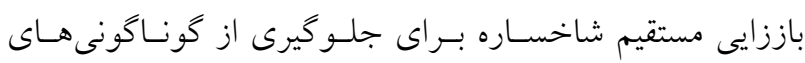

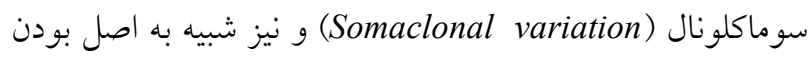

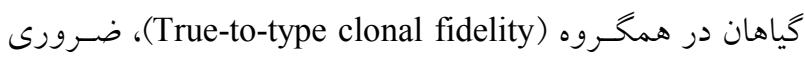
است (1)). در باززايى شاخساره از بافتهـاى يينـه (كـالوس)،

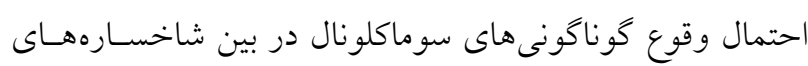

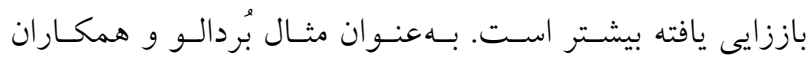

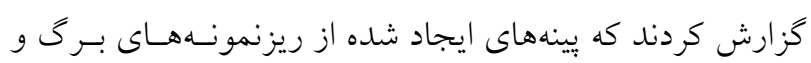

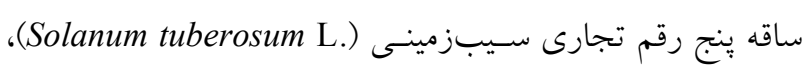

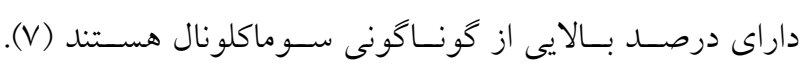

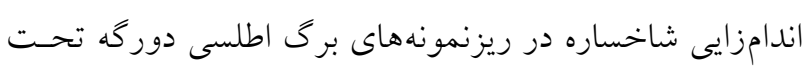

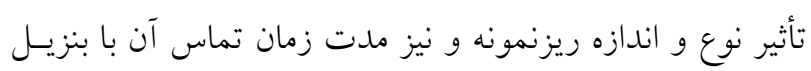

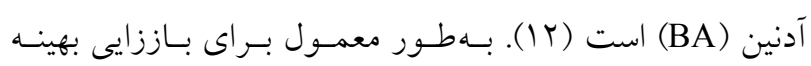

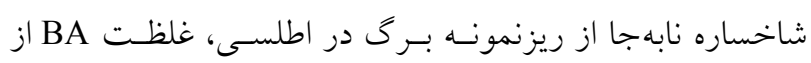

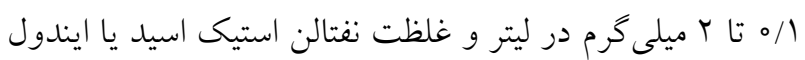

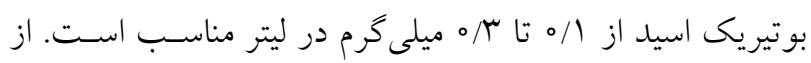

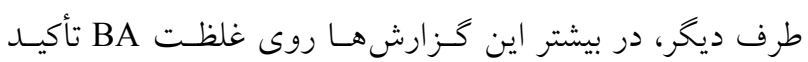

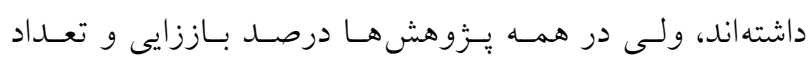

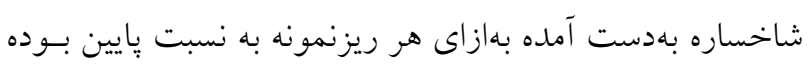

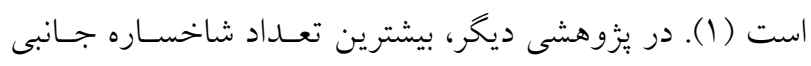

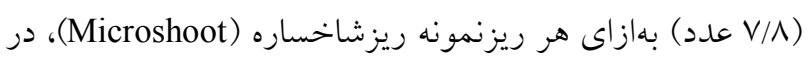

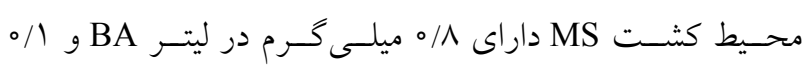

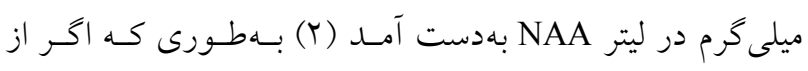




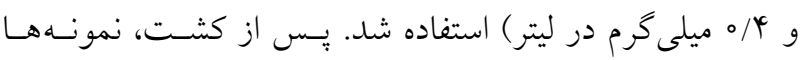

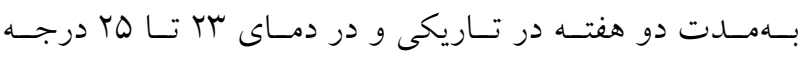

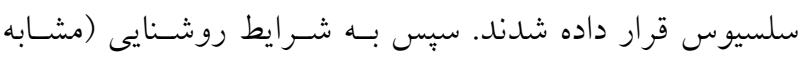

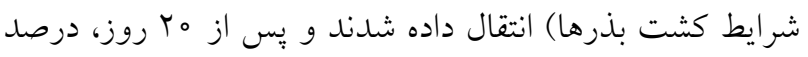

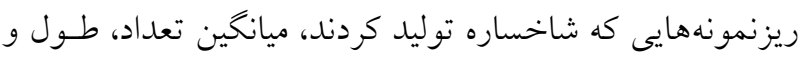

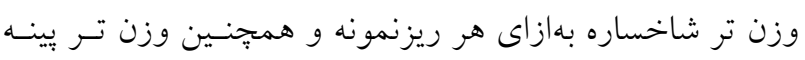

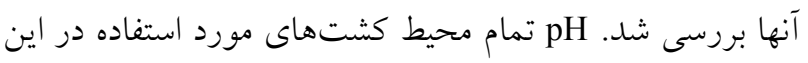
يزٔوهش بـا استفاده از NaOH و HCl

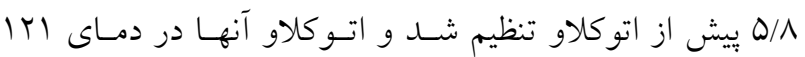

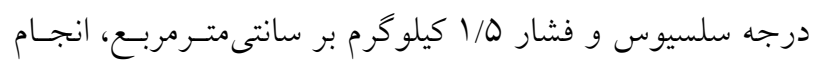

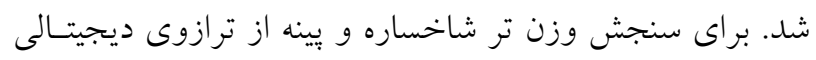

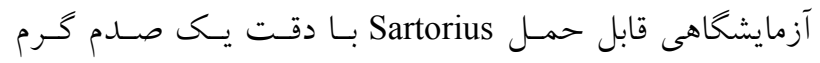

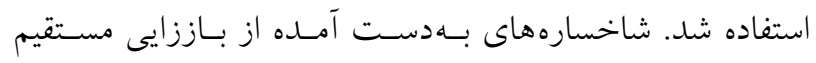

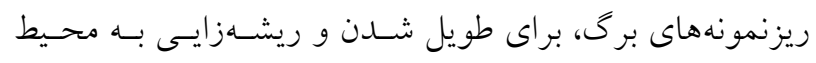

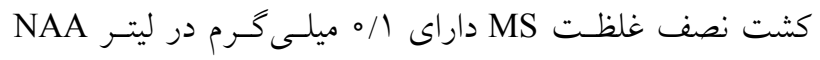

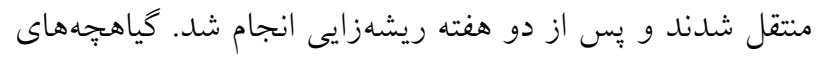

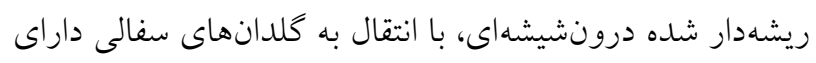

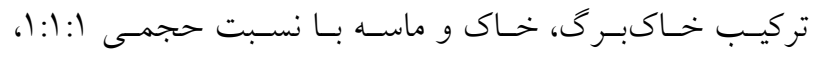
بلهصورت موفقيت آميزى در شـر ايط كالخانـه سـازكارى يافتنــا.

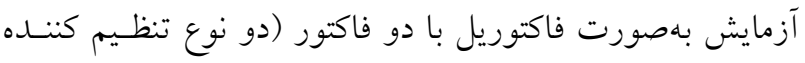
رشد BA و NAA هر كدام در جهار سطح) در قالب طرح كاملاً

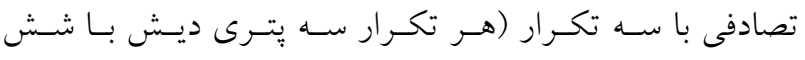

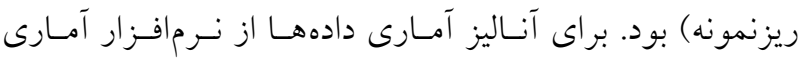
MSTAT-C درصد با آزمون LSD مقايسه شدند.

نتايج همجنــان كـه در جـــول تجزيسه واريـانس (جــول () مشـاهده مىشود اثر متقابل BA در NAA بر همه صفات اندازهگيرى شــده

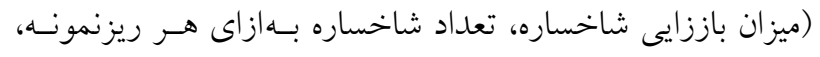

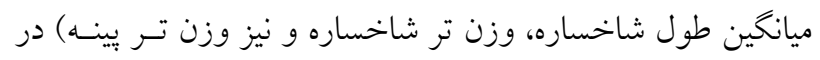

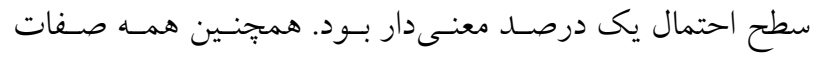

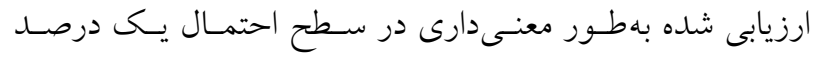

قابليت توليد شاخساره نابهجا، با استفاده از اين تنظيم كنــدهـاى

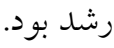

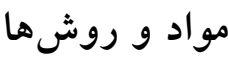

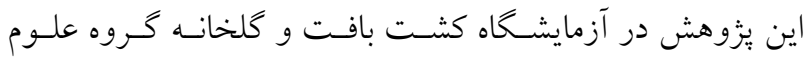

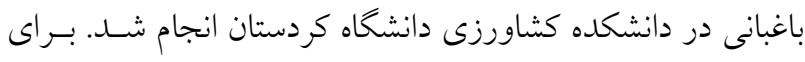

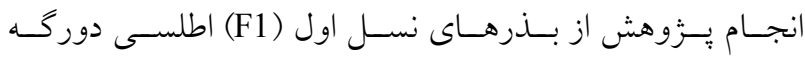
تهيــ (P. hybrida cv. Petunia Eagle Pink Vein Hybrid F1)

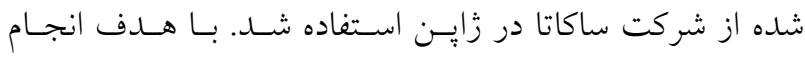

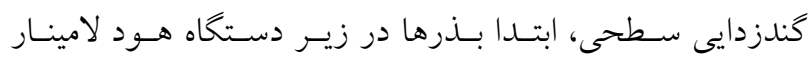

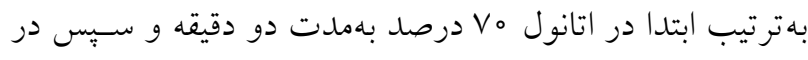

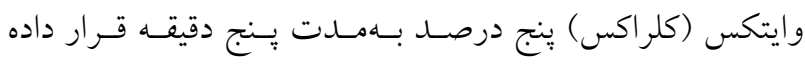

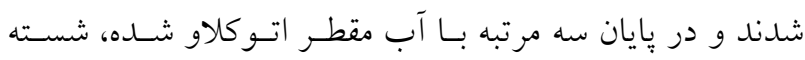

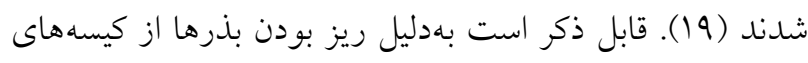

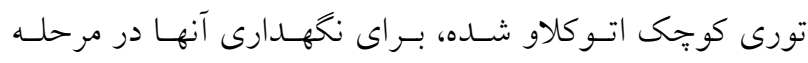

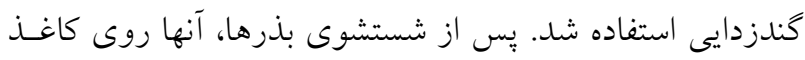

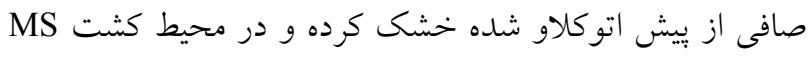

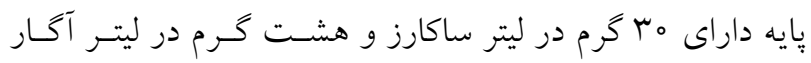
كشت شدند. سبس بذرهاى كشت شده در شيشه دها، در شـرايط

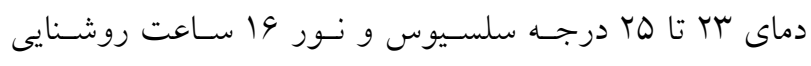

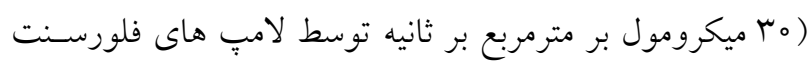

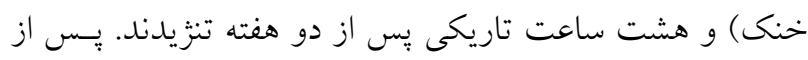

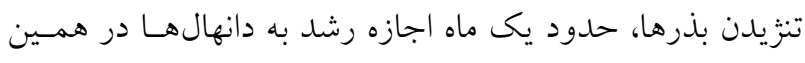

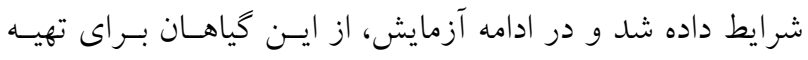

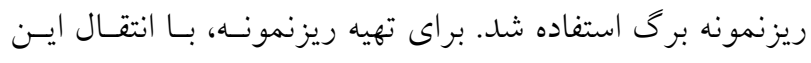

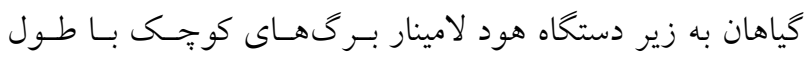

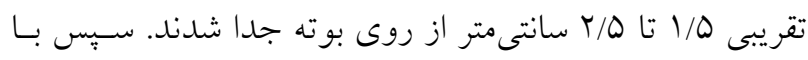
نصف كردن بركها از وسط و حذف لبههاى برى، هر كـدام از

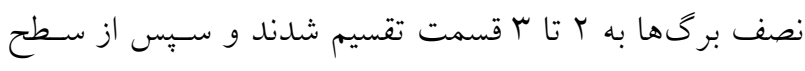
نامحور سو (Abaxial) بهصورت افقى روى محسيط كثـت MS

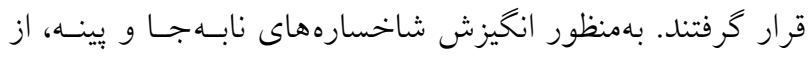

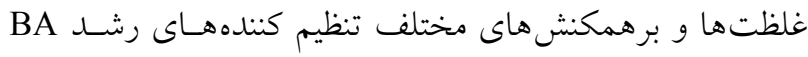

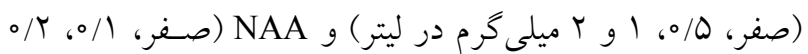


جدول ا. نتايج تجزيه واريانس (ميانخين مربعات) اثر غلظتهاى مختلف BA و NAA، بر باززايى مستقيم شاخساره نابهجا و نيز توليد بينه از ريزنمونه ايى برى اطلسى دورگه

\begin{tabular}{|c|c|c|c|c|c|c|}
\hline وزن تر بينه & وزن تر شاخساره & ميانخين طول شاخساره & تعداد شاخساره هر ريزنمونه & $\begin{array}{c}\text { باززايى شاخساره } \\
\text { (درصد) }\end{array}$ & 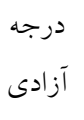 & منابع تغيير \\
\hline$\circ / \mu \Lambda \Lambda^{* *}$ & $1 \mathrm{~V} / 9 \mathrm{~V} \mathrm{~V}^{* *}$ & $Y Y / 4 V Y^{* *}$ & $Y Y Y / T Q \Lambda^{* *}$ & $19 \circ 9 \circ / 49 r^{* *}$ & $r$ & بنزيل آدنين (BA) \\
\hline$\circ / \Lambda F Y^{* *}$ & $\circ / 19 \Lambda^{\mathrm{ns}}$ & $\circ / \Upsilon \wedge 0^{*}$ & $1 \circ / 4 V Q^{* * *}$ & $\operatorname{cr} 4 / 99 \varphi^{* *}$ & r & نفتالن استيك اسيد (NAA) \\
\hline$\circ / \circ 9 \wedge^{* *}$ & $\varphi / \Delta V^{\omega * *}$ & $\circ / \mu G \psi^{* * *}$ & $\Delta Y / 90^{\circ * *}$ & $r Y V Y / Y q Y^{* *}$ & 9 & $\mathrm{BA} \times \mathrm{NAA}$ \\
\hline$\circ / \circ \circ 4$ & $\circ / 11 \circ$ & $\circ / \circ \vee \wedge$ & -/9YQ & GY/०० & re & خطا \\
\hline IV/VQ & $19 / 0 r$ & $10 / 01$ & $14 / 94$ & $\mid r / \Lambda \Delta$ & - & ضريب تغييرات \\
\hline
\end{tabular}

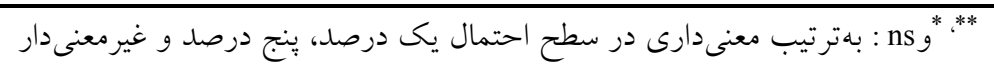

جدول r. نتايج مقايسه ميانخين اثر BA و NAA بر درصد باززايى شاخساره در ريزنمونهاى برى گل اطلسى دورگه

\begin{tabular}{|c|c|c|c|c|c|}
\hline \multicolumn{5}{|c|}{ NAA (ميلى گرم در ليتر) } & \multirow{2}{*}{ 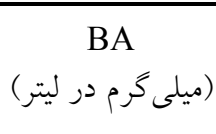 } \\
\hline ميانخين & $\circ / 4$ & $\circ / r$ & $\circ / 1$ & صفر & \\
\hline$\circ / \circ \mathrm{D}$ & $\circ / 00^{\mathrm{e}}$ & $\circ / 00^{\mathrm{e}}$ & $\% / 00^{\mathrm{e}}$ & $\circ / 00^{\mathrm{e}}$ & صفر \\
\hline QN/AYC & Y०/००c & 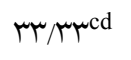 & Gr/Mrb & $100 \% 0^{a}$ & $\circ / 0$ \\
\hline$\Lambda \Lambda / \Delta \Lambda^{\mathrm{A}}$ & $94 /$ ra & $100 / 00^{a}$ & arra & $49 / 9 \mathrm{~V}^{\mathrm{b}}$ & 1 \\
\hline \multirow[t]{2}{*}{$\vee q / \wedge \varphi^{B}$} & $100 / 00^{a}$ & $100 / 00^{a}$ & arra & $r \& / 11^{d}$ & r \\
\hline & $\Delta \wedge / \Delta \wedge^{\mathrm{A}}$ & Q/ NMA & $G Y / r \Delta^{\mathrm{A}}$ & $4 / 19^{B}$ & ميانخين \\
\hline
\end{tabular}

ميانخين هاى داراى حروف مشترك، براساس آزمون LSD در سطح احتمال ينج درصد اختلاف معنى دار ندارند.

درصد) در محيط كشت داراى دو ميلى گـرم در ليتـر BA بـدون NAA بود. نتايج نشان داد جنانجه از BA بهتنهايى استفاده شـود در غلظت هاى يايين نتايج بهترى دارد جيون طبق نتايج بـهدسـت

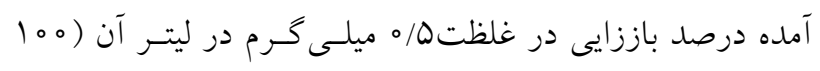

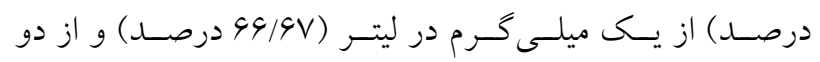
ميلى گرم در ليتر ( تركيب با NAA استفاده شود، غلظتهاى بـالاتر آن مناسـبـــر بود (جدول Y). در تيمارهـاى تركيبى يـكى ميلى گـرم در ليتـر

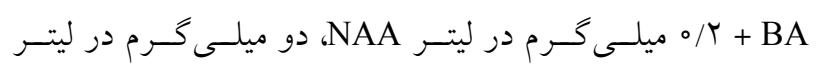
NAA همه ريزنمونه NA BA

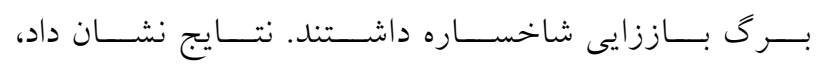

تحت تأثير اثر ساده NAA قرار گرفتند. افزون بـر ايسن، BA اثـر

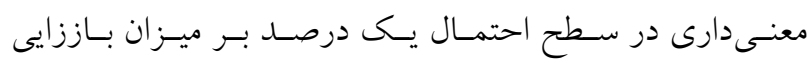
شاخساره، تعداد شاخساره بهازاى هر ريزنمونـه و وزن تـر بينـهـ داشت، اما اثر آن بر ميانخين طول شاخسـاره در سـطح احتمـال

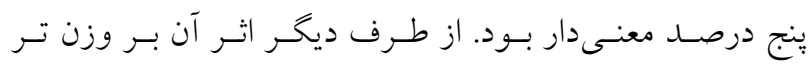
شاخساره غيرمعنىدار بود (جدول (). يس از يك ماه از كاربرد تنظيم كنندههاى رشد BA و NAA بهتنهايى و يا در برهمكنش باهم براى باززايى مستقيم شاخساره

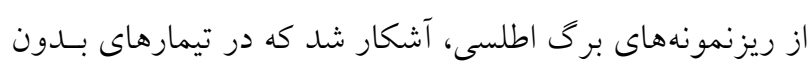
تنظيم كننده BA، هيج گونه باززايى شاخسارهاى انجام نمىشـود (جدول r). هم:جنين كمترين درصـد بـاززايى شاخسـاره ( ( 

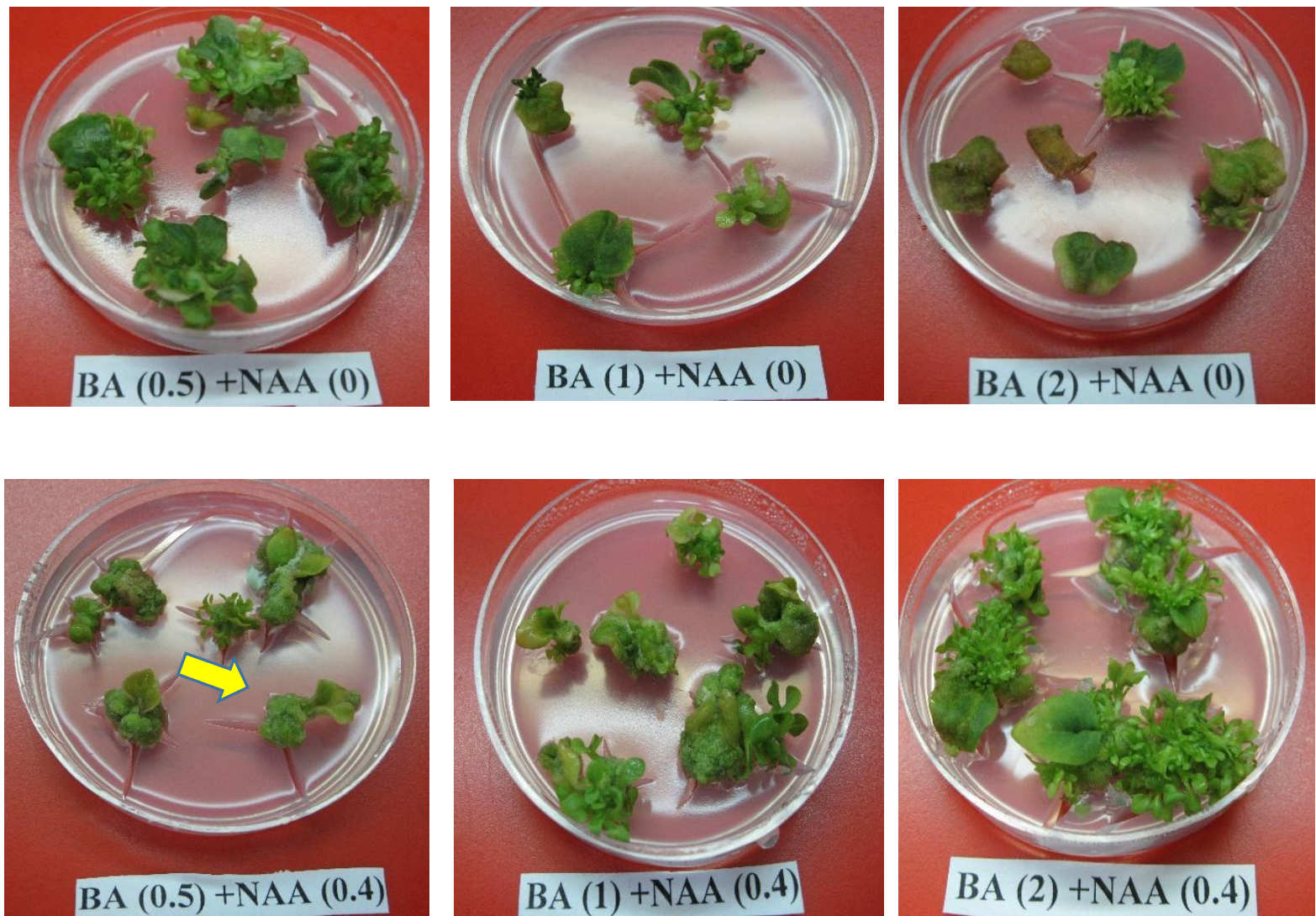

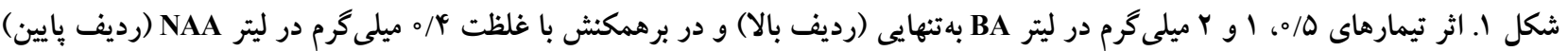

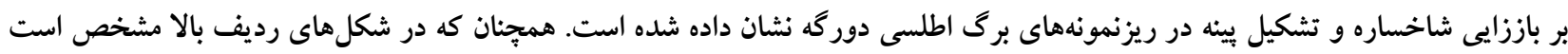

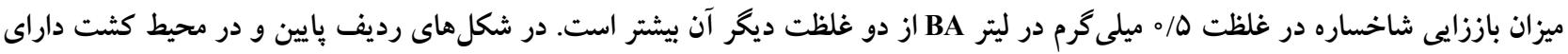

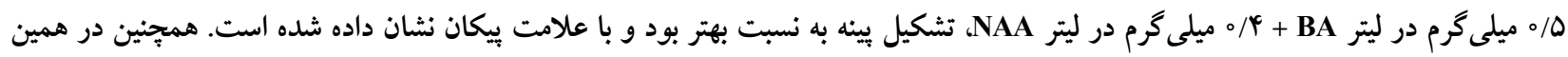

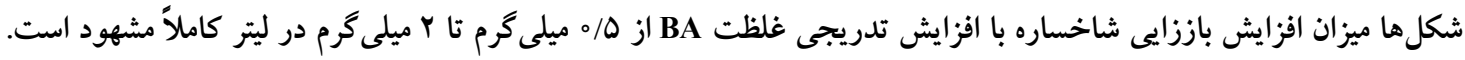

رشد BA بهتنهايى در غلظـتهـاى پـايين آن تعـداد شاخسـاره

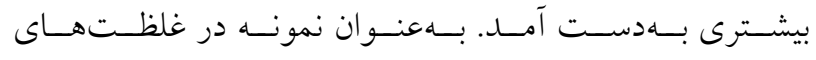

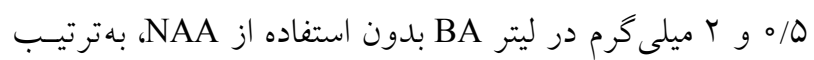

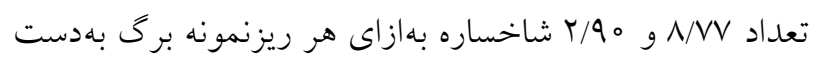

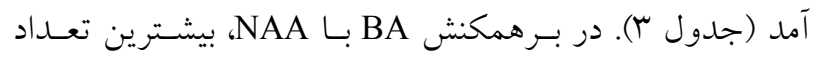

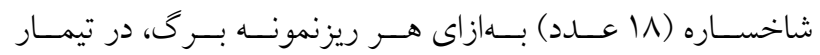

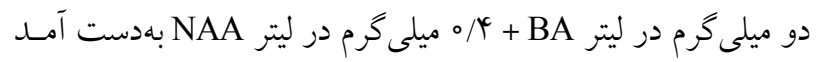

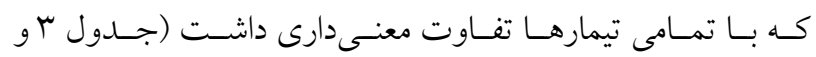

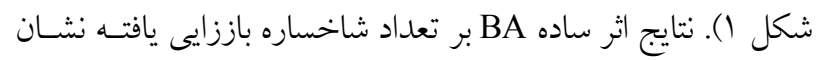

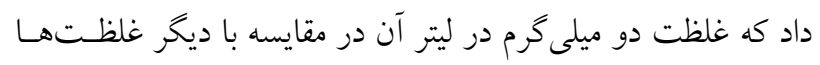

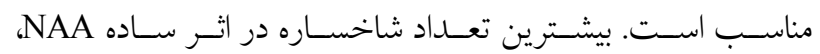

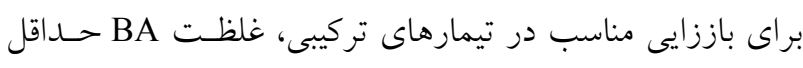

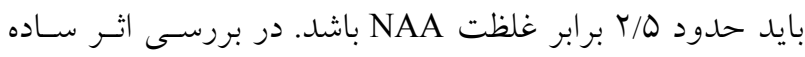

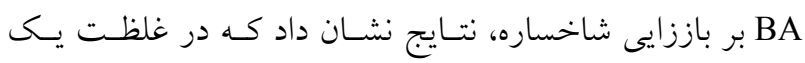

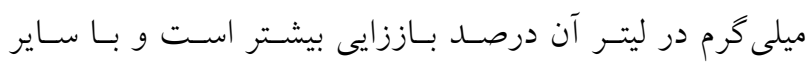

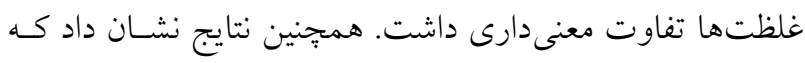

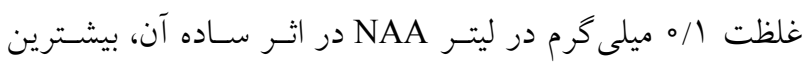

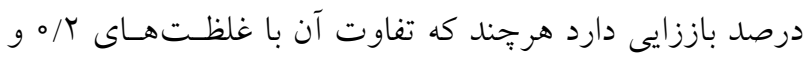

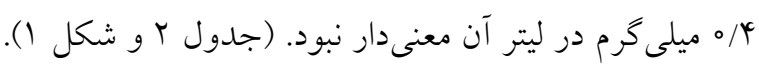
در محيط كشتهاى بدون تنظيم كنــده رشــ و و يـا محسيط كشتهايى كه تنها داراى NAA بودند، هيج شاخسـارهاى توليــ نشد (جدول ؟). مشابه باززايى شاخساره، استفاده از تنظيم كنده 
جدول r. نتايج مقايسه ميانخين اثر BA و NAA بر تعداد شاخساره باززايى يافته از يك ريزنمونه برگ اطلسى دورگه

\begin{tabular}{|c|c|c|c|c|c|}
\hline \multicolumn{5}{|c|}{ NAA (ميلى گرم در ليتر) } & \multirow{2}{*}{ 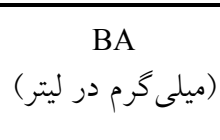 } \\
\hline ميانخين & $0 / 4$ & $\circ / T$ & $\circ / 1$ & صفر & \\
\hline$\circ / 00^{D}$ & $\circ / 00^{e}$ & $\circ / 00^{\mathrm{e}}$ & $\% / 00^{\mathrm{e}}$ & $\circ / 0 \circ \mathrm{e}$ & صفر \\
\hline$\varphi / \psi_{0} \mathrm{C}$ & $r / \circ \circ \mathrm{g}$ & $1 / 4_{0} h$ & $Y / Y_{0}$ ef & $\Lambda / V V^{c}$ & $\circ / 0$ \\
\hline$G \pi V^{B}$ & $\mathrm{r} / \Lambda \circ \mathrm{fg}$ & $10 / 9 \mathrm{Vb}^{\mathrm{b}}$ & $\Delta / v Q^{\mathrm{d}}$ & $Q / Y V$ de & 1 \\
\hline \multirow[t]{2}{*}{$1 \circ / 4 \circ A$} & $M / \circ \circ a$ & $11 / \mathrm{V} \circ \mathrm{b}$ & $9 / 0 \circ c$ & $r / Q \circ g$ & r \\
\hline & $9 / Y \circ A$ & $\Delta / 9 C^{\mathrm{A}}$ & $\varphi / V q^{B}$ & $4 / \mu^{B}$ & ميانخين \\
\hline
\end{tabular}

ميانخينهاى داراى حروف مشترك بر اساس آزمون LSD در سطح احتمال ينج درصد اختلاف معنىدار ندارند.

جدول f. نتايج مقايسه ميانگين اثر ساده و برهمكنش BA و NAA بر طول شاخساره (سانتىتر) باززايى يافته در ريزنمونهاى برى گل اطلسى دورگه

\begin{tabular}{|c|c|c|c|c|c|}
\hline \multicolumn{5}{|c|}{ NAA (ميلى گرم در ليتر) } & \multirow{2}{*}{$\begin{array}{c}\text { BA } \\
\text { (ميلى گرم در ليتر) }\end{array}$} \\
\hline ميانخين & $\circ / 4$ & $\circ / 4$ & $\circ / 1$ & صفر & \\
\hline$\circ / \circ \circ D$ & $\circ / \circ \circ f$ & $\circ / \circ \circ f$ & \%/००f & $\circ / \circ \circ f$ & صفر \\
\hline$r / r q A$ & $\Gamma / M^{b c}$ & $0 / 1 \circ a$ & $\kappa / \backslash \wedge^{b}$ & $r / 0 \circ b c$ &.$/ 0$ \\
\hline$\Gamma / \wedge^{B}{ }^{B}$ & $y / \circ \circ b c$ & $\Gamma / \Delta V^{c}$ & $r / q_{\circ} b c$ & $\Gamma / 99^{c}$ & 1 \\
\hline \multirow[t]{2}{*}{$r / \circ q^{C}$} & T/V $V^{e}$ & $r / l$ de & $\Gamma / \Delta \Delta^{c d}$ & $\mathrm{r} / 9 \mathrm{~N}^{\mathrm{e}}$ & r \\
\hline & $r / 94 \mathrm{~B}$ & T/QYAA & $\mathrm{r} / 9)^{\mathrm{A}}$ & T/94B & ميانگين \\
\hline
\end{tabular}

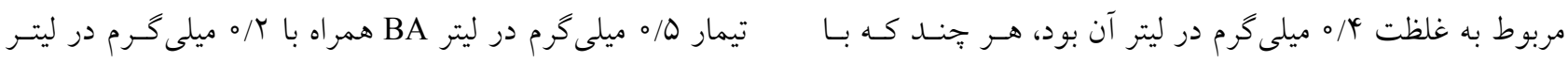

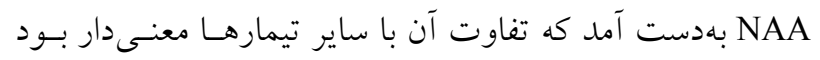

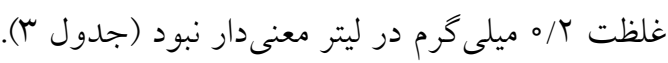

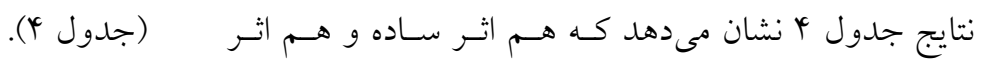

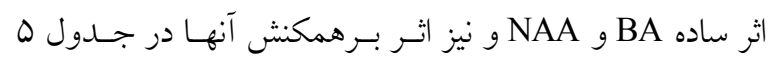

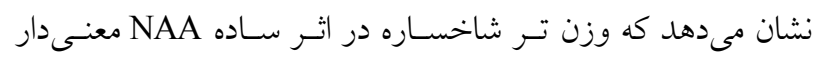
نيست. در بررسى اثر ساده BA بر وزن تر شاخسـاره، نتـايج نشـان

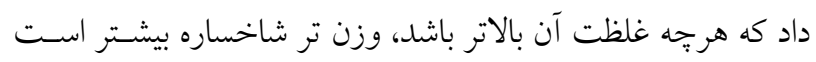
و بيشترين مقدار وزن تر شاخساره در غلظت دو ميلى خـرم در ليتـر

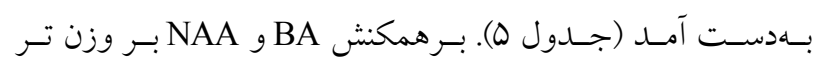

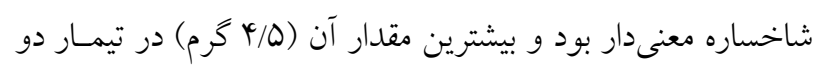

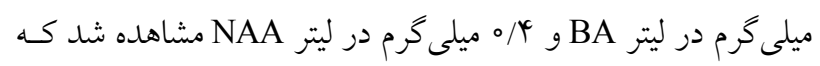
تفاوت معنىدارى با ساير تيمارها داشت (جدول ها ه).

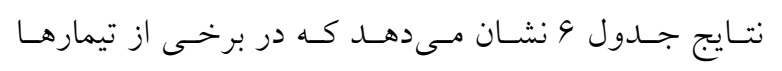
برهمكنش BA و NAA بر طول شاخسارههاى باززايى يافتسه از

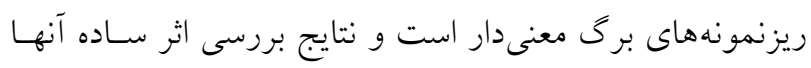

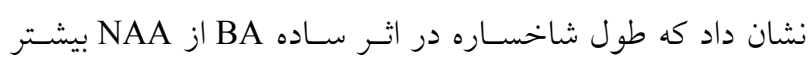
است. همجِنين، بيشترين طول شاخساره (Y/QY سانتىمتر) در اثر

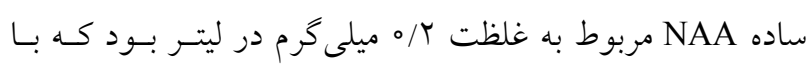

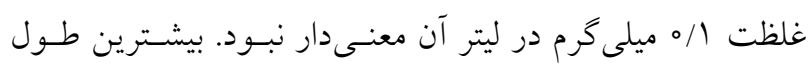

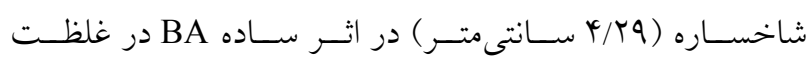

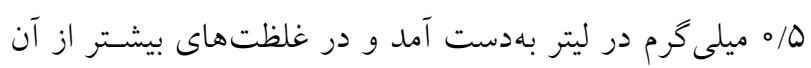

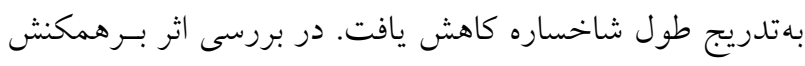

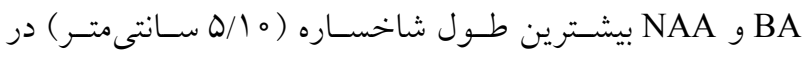


جدول ه. نتايج مقايسه ميانخين اثر ساده و برهمكنش BA و NAA بر وزن تر (گرم) شاخسارههاى باززايى يافته از ريزنمونهاى برى گل اطلسى دور گه

\begin{tabular}{|c|c|c|c|c|c|}
\hline \multicolumn{5}{|c|}{ NAA (ميلى گرم در ليتر) NAA } & \multirow{2}{*}{ 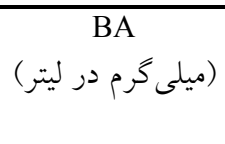 } \\
\hline ميانكين &.$/ 4$ & $0 / T$ & $0 / 1$ & صفر & \\
\hline$\% \% \mathrm{D}$ & $\% / 00^{f}$ & $\% / 0{ }^{f}$ & $\% / \circ 0^{f}$ & $\% / \circ o^{f}$ & صفر \\
\hline$I / N I^{C}$ & $1 / 09$ ef & $\circ / 9 \Delta^{f}$ & $1 / 99^{\mathrm{cd}}$ & r/AYb &.$/ 0$ \\
\hline$r / T Y^{B}$ & $1 / 4 \gamma^{\mathrm{de}}$ & $r / 4 Y^{b}$ & $r / \circ \wedge^{c}$ & $1 / 9 \wedge^{c}$ & 1 \\
\hline \multirow[t]{2}{*}{$\Gamma / \Lambda \otimes^{\mathrm{A}}$} & $Y / 0 \circ 0^{a}$ & $r / \Gamma \Lambda^{\mathrm{b}}$ & $r / \Lambda \Lambda^{b}$ & $\circ / N Q^{f}$ & r \\
\hline & $1 / V Q^{A}$ & $1 / N F^{A}$ & $1 / 9 \mathrm{VA}^{\mathrm{A}}$ & $1 / \Delta \mu^{A}$ & ميانخين \\
\hline
\end{tabular}

ميانخينهاى داراى حروف مشترك بر اساس آزمون LSD در سطح احتمال بنج درصد اختلاف معنىدار ندارند.

جدول 9. نتايج مقايسه ميانكين اثر ساده و برهمكنش BA و NAA بر وزن تر بينه (كرم) باززايى يافته از ريزنمونههاى برى اطلسى دور گه

\begin{tabular}{|c|c|c|c|c|c|}
\hline \multicolumn{5}{|c|}{ (ميلى گرم در ليتر) NAA } & \multirow{2}{*}{$\begin{array}{c}\text { BA } \\
\text { (ميلى كرم در ليتر) }\end{array}$} \\
\hline ميانخين & $\circ / 4$ & $0 / r$ & $0 / 1$ & صفر & \\
\hline $1 / / r^{B}$ & $1 / 0 \circ e$ & $1 / 9 \mathrm{Vde}$ & $1 / \pi r e$ & $\circ / \circ \circ$ & صفر \\
\hline $1 / N \psi^{A}$ & $r / I V^{a}$ & $r / I V^{c}$ & T/oodd & $\% / \circ \mathrm{of}^{\prime}$ & $\circ / 0$ \\
\hline$\circ / V^{C} C$ & $\% / 0 \circ f$ & $r / 0$ oab & $\% \circ \mathrm{of}^{\mathrm{f}}$ & $\% / \circ o^{f}$ & 1 \\
\hline \multirow[t]{2}{*}{$\circ / 9 \mathrm{VC}^{\mathrm{C}}$} & $r / 9 V^{b}$ & $\% \circ o^{f}$ & $\% \circ o^{f}$ & $\% / \circ \mathrm{f}$ & r \\
\hline & $1 / A r^{\mathrm{A}}$ & $|/ N|^{A}$ & $\circ / \Lambda r^{B}$ & $\circ / \circ \mathrm{C}$ & ميانخين \\
\hline
\end{tabular}

ميانكَينهاى داراى حروف مشترك بر اساس آزمون LSD در سطح احتمال ينج درصد اختلاف معنىدار ندارند.

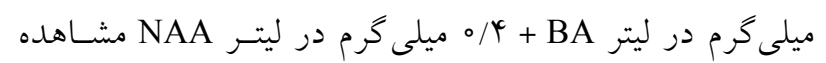

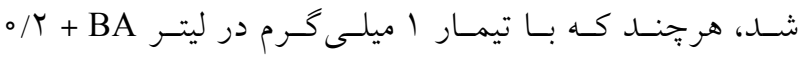

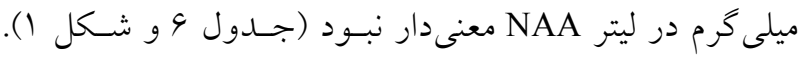
برخلاف NAA، در تيمارهاى BA بهتنهايى، هيج كونسه يينـاى

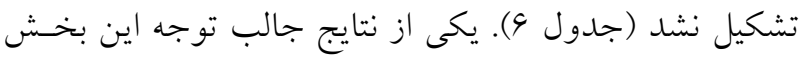

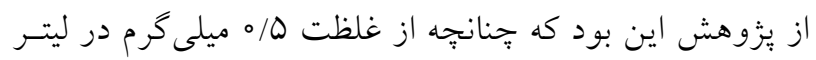

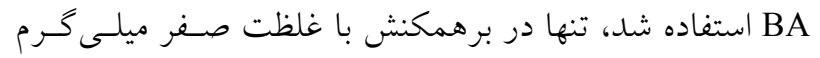

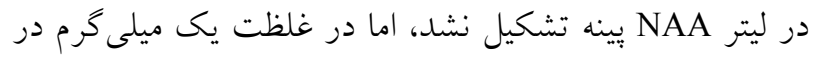
ليتر BA در غلظتهاى صفر و l/ه ميلى

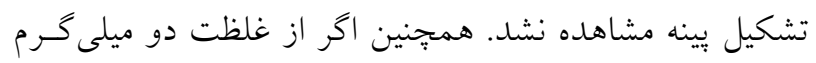

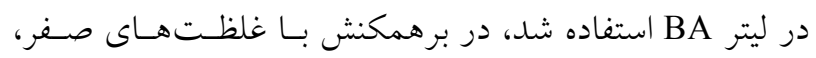
/ / و / / ميلى گرم در ليتر NAA يينهاى تشكيل نشد.
هيج گونه بينهاى تشكيل نشد. اثر ساده NAA بر وزن تـر يينـه بهدست آمده از ريزنمونههاى برى اطلسى، معنى دار شـــ و در

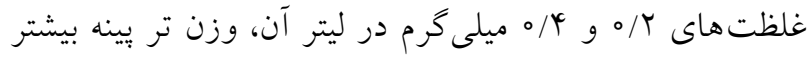

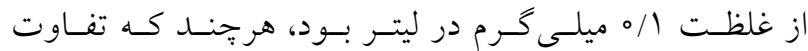
معنسيدارى بـين ايسن دو غلظـت وجـود نسـارد (جسـول 9).

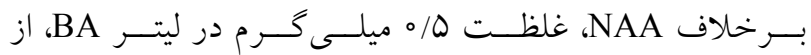

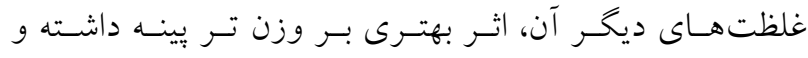
بيشترين وزن تر در اين غلظت مشـاهده شـد. در بررسى اثتر

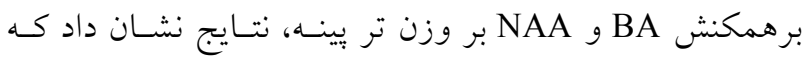

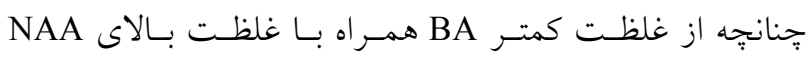

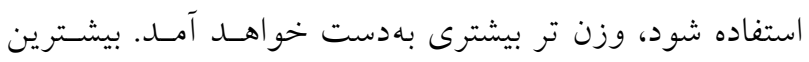

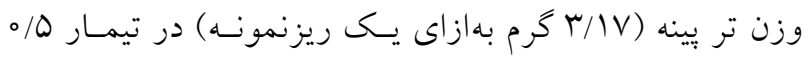



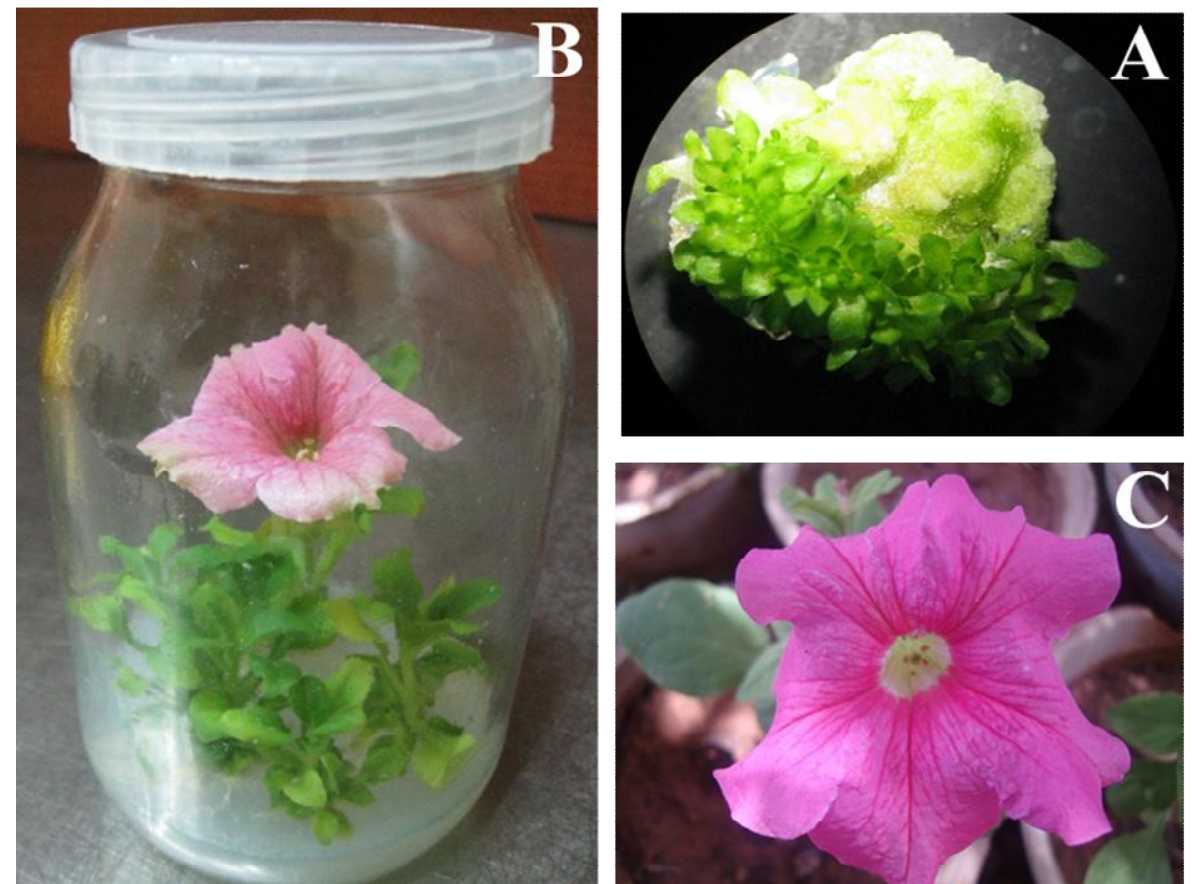

شكل Y. A: باززايى شاخسارهها از بينه توليد شده از ريزنمونهاى برى روى محيط كشت MS داراى ه/ه ميلى B: گل دهى درونشيشهاى يكى از شاخسارهاى باززايى يافته در مرحله ريشهدهى روى محيط كشت نصف غلظت MS داراى / /ه ميلى گرم

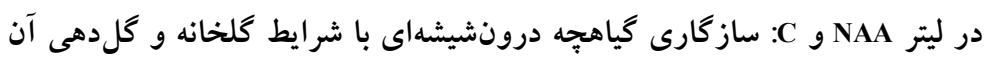

در تيمارهايى كه داراى NAA بهتنهايى بودند، رنخ بينه كـرم و بحث اكر جهه باززايى غيرمستقيم شاخساره از بافت هاى بينـه، روش بــا

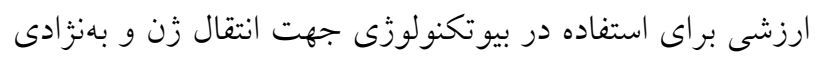
قهوهاى بود، ولى در تيمارهايى كه داراى BA هم بودند بسته بـهـ

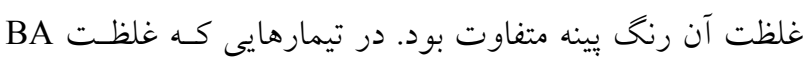

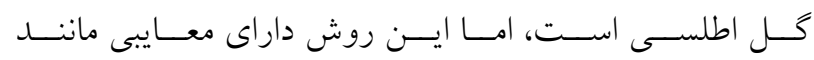
كوناگونى هاى سوماكلونال در بين شاخسارههـاى بـاززايى يافتـه كمتر بود، رنخ بينه قهوهاى متمايل به سبز بود و در غلظتهـاى

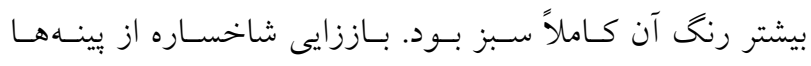
است (Y). برخلاف اين روش، اندامزايى مستقيم شاخساره يكى از مهمترين رخدادهاى مورفوزنتيك در ريزافزايى كياهان است،

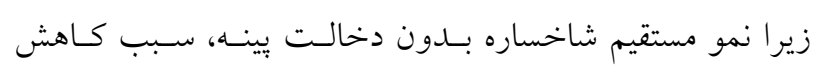
معنى دارى در گوناگونى هاى سوماكلونال مىشود (با). در واقع

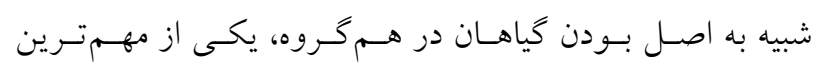

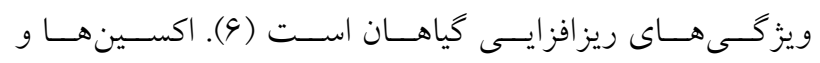
سايتو كينينها، در بسيارى از جنبه هاى رشدونمو گياهان اهميـت ريت دارند و نيـز نقـش انكارنايــذيرى در فراينــدهاى تمـايززدايى و بازتمايزيابى در گياهان دارند. بهطوركلى يذيرفته شده كه اين دو

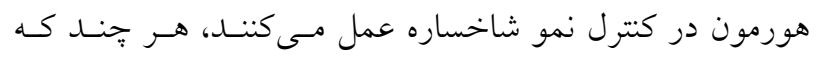
بهراحتى در محيط كشت MS داراى Q/ه ميلى انجام شد (شكل r-Y). همجنين شاخسارههاى بهدست آمده از باززايى مستقيم ريزنمونه هاى برگ، بهسهولت در محسيط كشـت نصف غلظت MS داراى / / ميلى گرم در ليتر NAA يس از دو

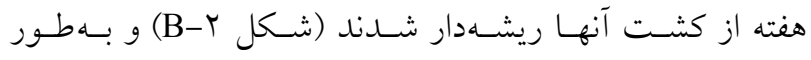
موفقيتآميزى با شرايط كلخانـه سـاز كار يافتنــ (شـكل r-C).

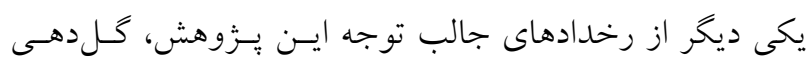
برخسى از شاخسـارههــا بـهـصـورت درونشيشـهاى در هنخــام ريشهدهى بود (شكل r-B)، كه اين در واقع نشاندهنده يكى از مزيتهاى ريزافزايى يراى كاهش طول دوره نونهالى است. 
شد. افزون بر اين، گزارش شده كه سايتوكينينها سبب تبــيل

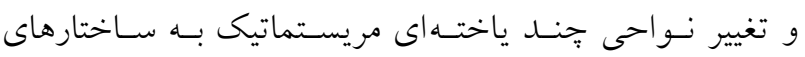

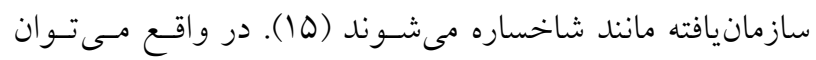

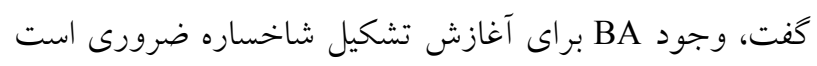

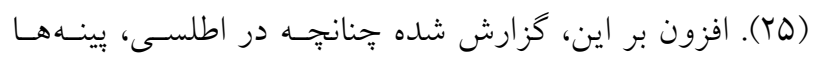

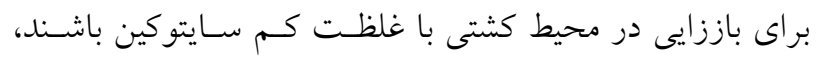

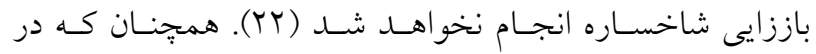

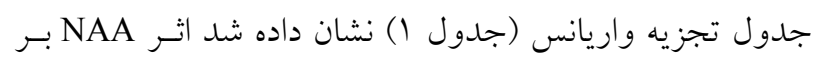

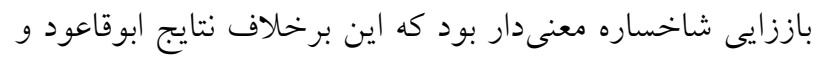

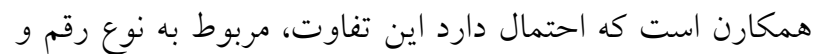

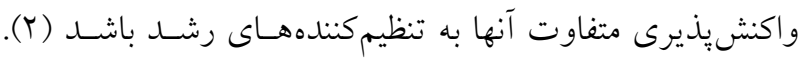

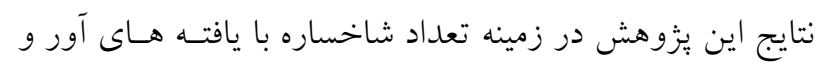

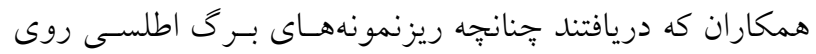
محيط كشت داراى BA كشت شوند، بهطسور معنسدارى سـبب افزايش تعداد شاخساره خواهد شد، همسو است (†). افزون بـر

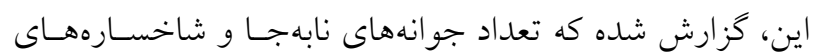

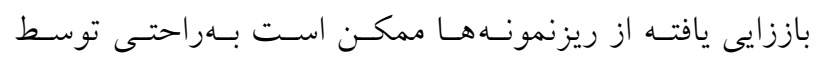

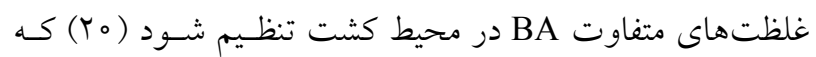

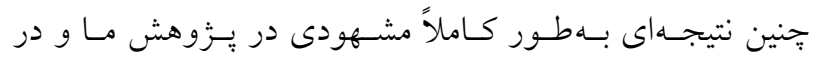

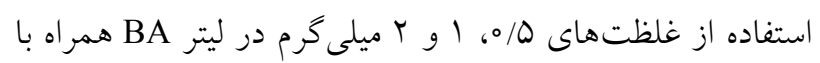

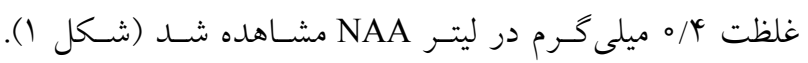

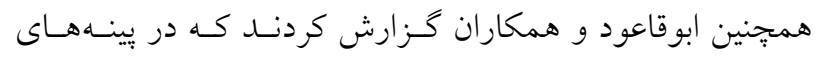

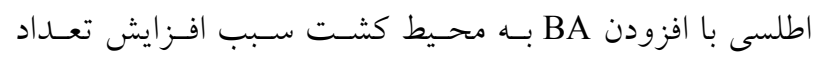

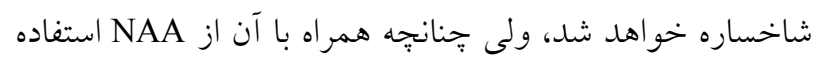

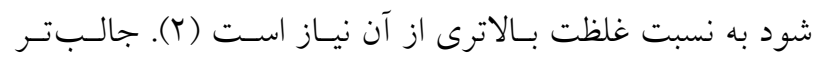
اينكه، در يُوهش حاضر وقتى از BA بهتنهايى استفاده شــ، در

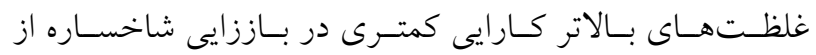

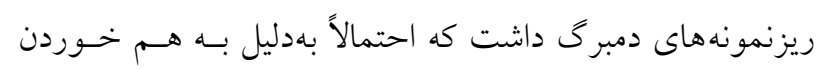
سطح تعادل هورمونى در ريزنمونه بوده است. همجنين احتمـال

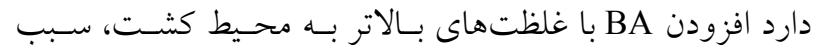
افزايش فعاليت آنزيم سايتوكينين اكسيداز و بدين ترتيسب سـبب

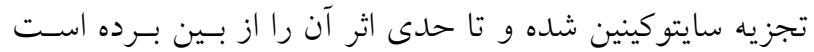

عوامل بيوشيميايى، فيزيولوزى و زنتيكى در ايـن تنظيم نقـش

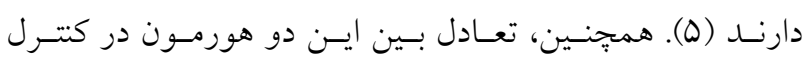

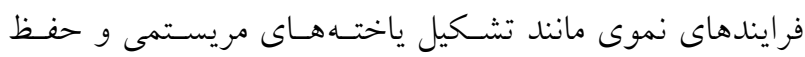

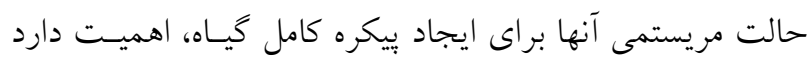

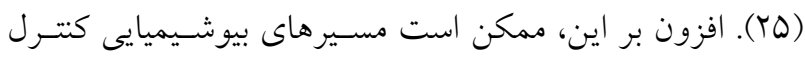

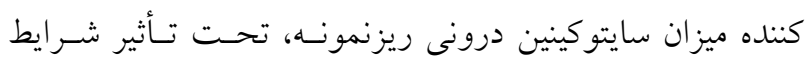

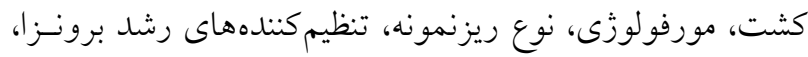

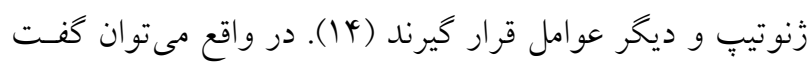

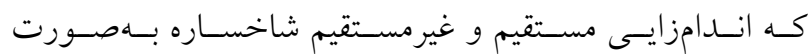

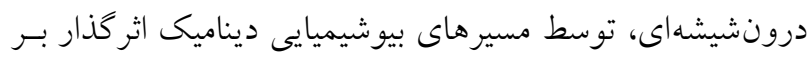
مقدار سايتوكينينهاى درونزا و برونزا، كنترل مىشود (ه).

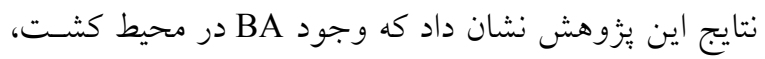

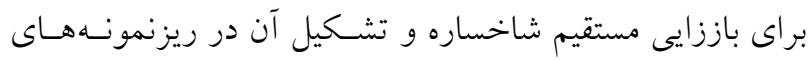
برگ اطلسى ضرورى است و حتى بلتنهايى و بدون استفاده بـا

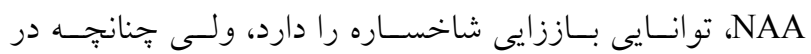
تركيب با NAA استفاده شد، كارايى آن بهتر مىشود. اين نتسايج

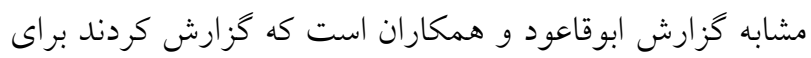

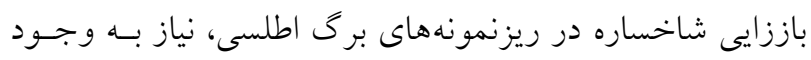

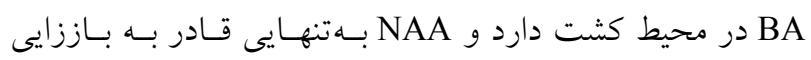

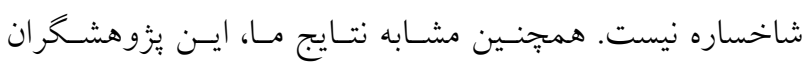

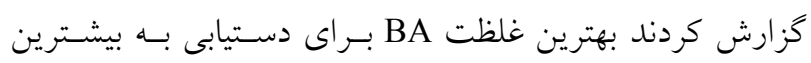

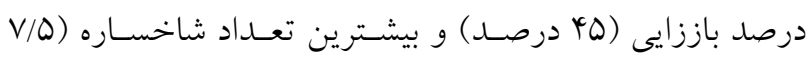
شاخساره) بهازاى هر ريزنمونه برگ، غلظت دو ميلى گرم در ليتر

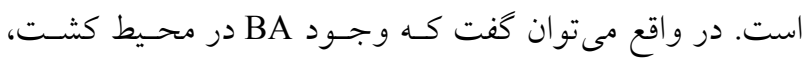

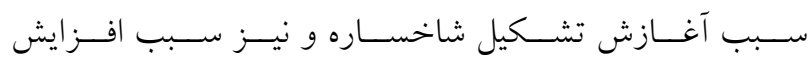

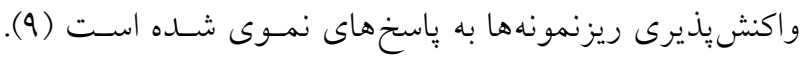

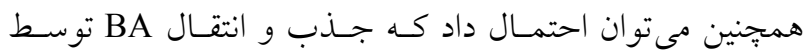

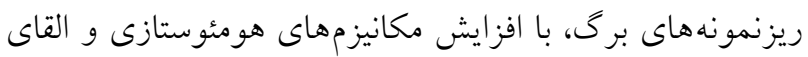
مسيرهاى بيامرسانى سيتوكينين، سبب بيان يكسرى از زنهـاى

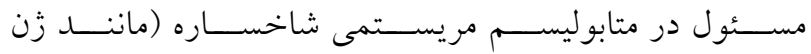

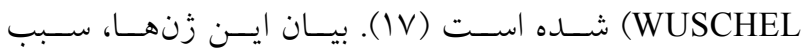
توانمندى ياخته هاى مريستمى براى باززايى شاخساره خو اهند 
كه اين نشاندهنده عدم نياز ضرورى اين رقم جهت توليـد بينـه

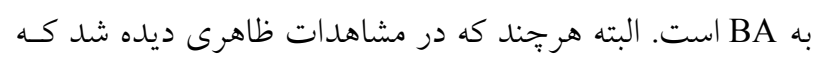

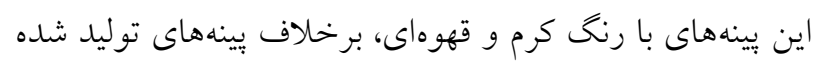

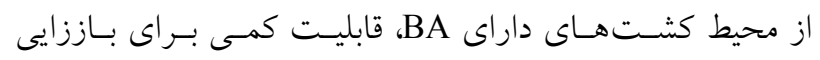

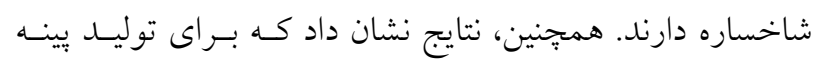

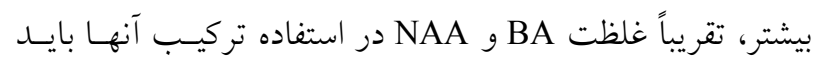
مساوى باشند. بيشترين ميزان بينه در محسيط كشـت MS و

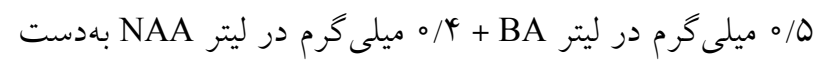

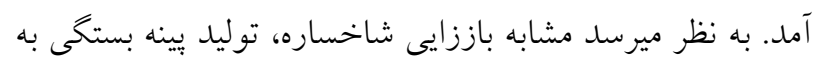

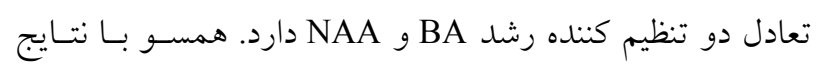

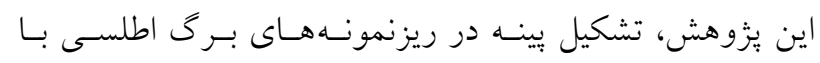
استفاده از BA، در محيط كشت MS كز عزارش شده است و تاكيد شده كه وجود BA در محيط كشت براى آغـازش تشـكيل بينـه

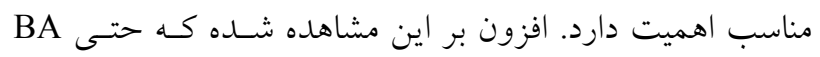

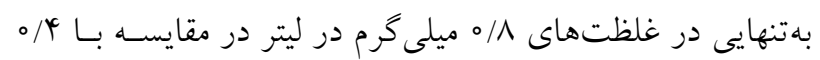

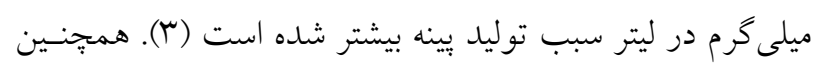

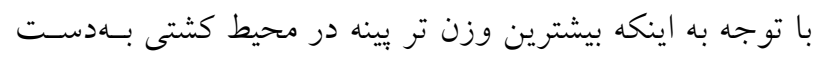

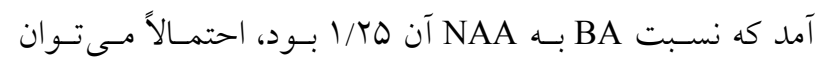

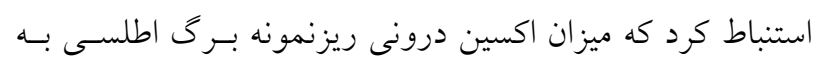

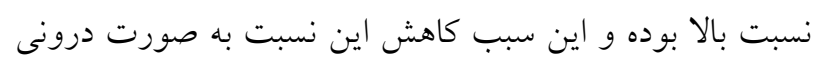
شده است.

\section{نتيجه گيرى}

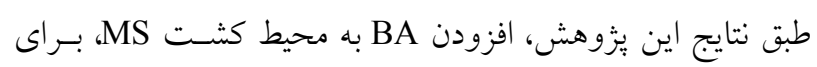

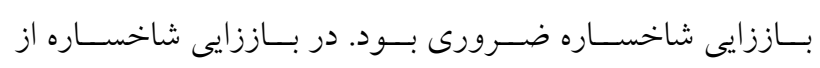

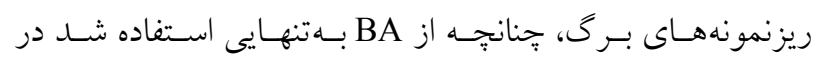

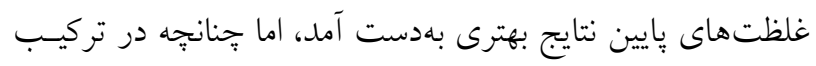

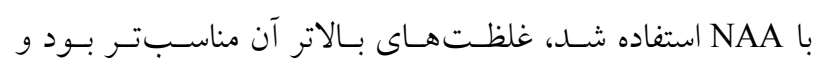

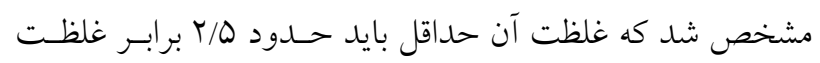

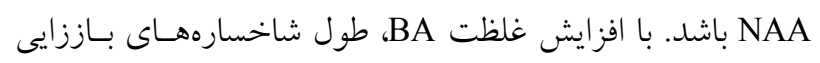

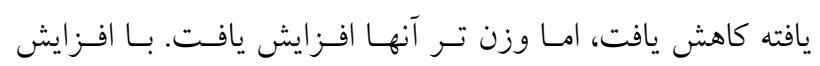

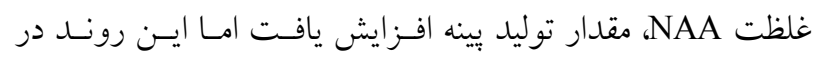

(D). بهطور كلى نتايج اين يزوهش و بهويـزّه در مـورد تعـداد و

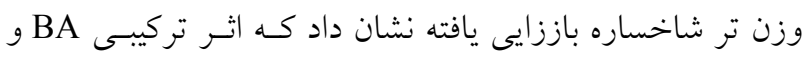

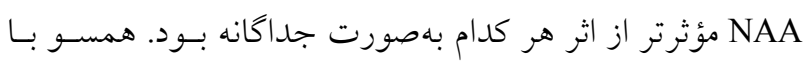

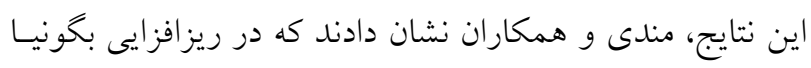

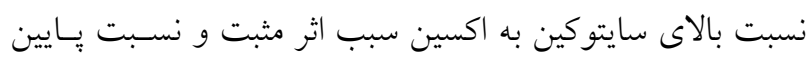

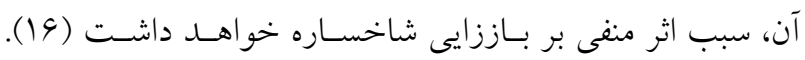

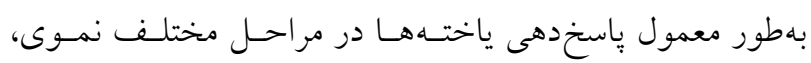

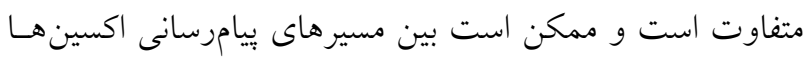

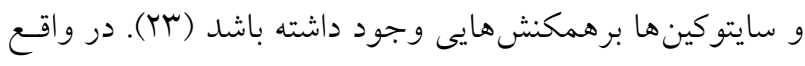

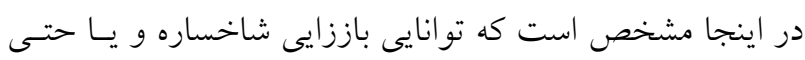
بينه، بستكى به تعادل اين دو هورمـون در محسيط كشــت و نيـز

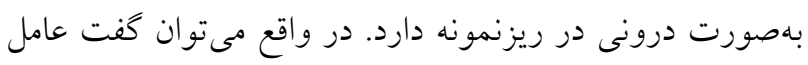

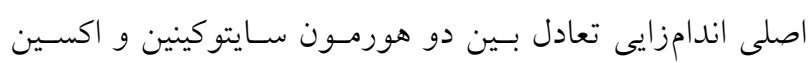

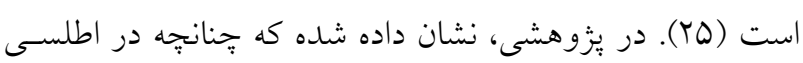

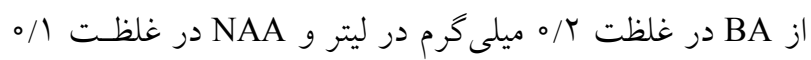
ميلى گرم در ليتر در تركيب با هم استفاده شود در تحريكى توليد

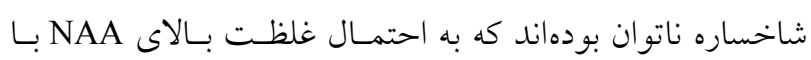

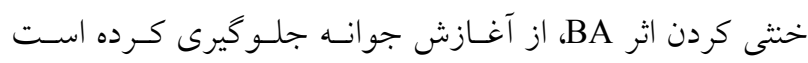

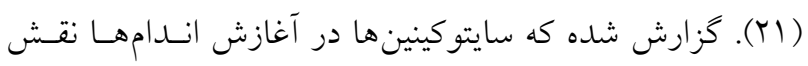
داشته و در مكانهايى از خياهان مانند مريستم انتهاى شاخسـاره

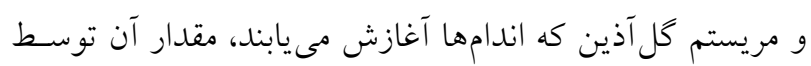

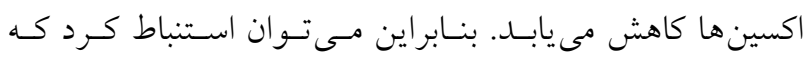

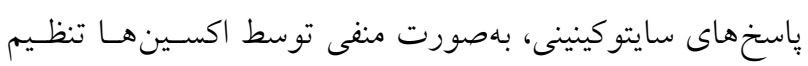

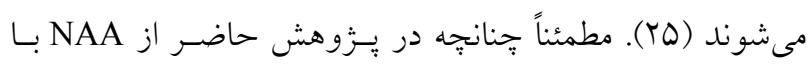

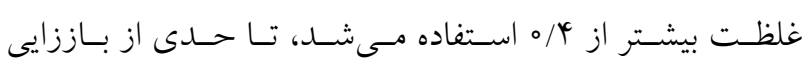

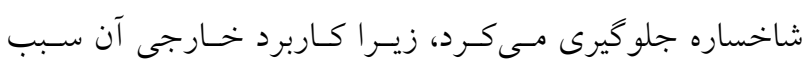

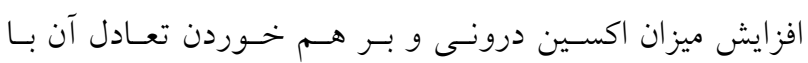

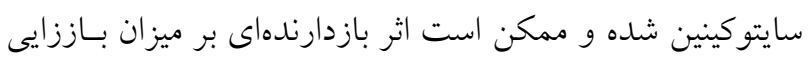

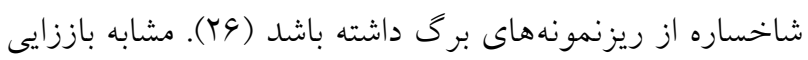

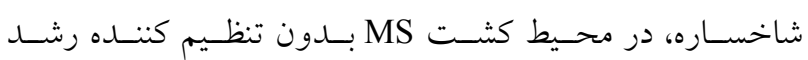

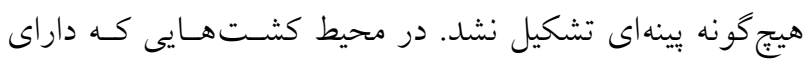
NAA بهتنهايى بودند، برخلاف BA تا حدى بينه توليد كردنـد، لئل 


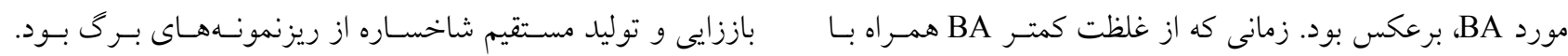

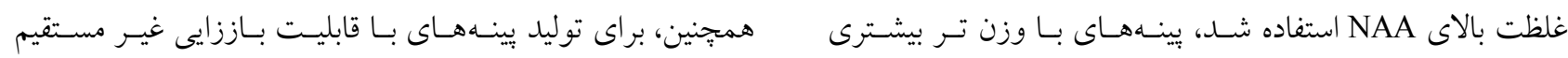

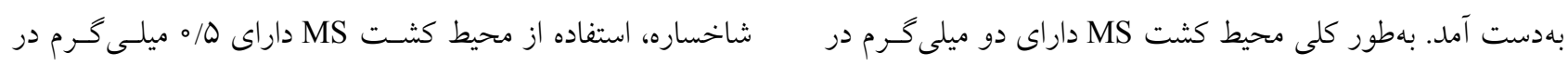

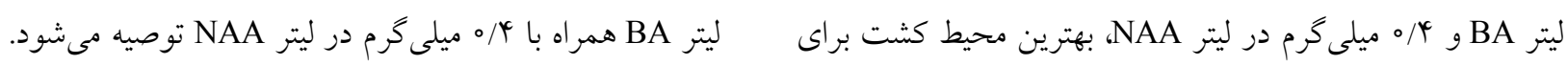

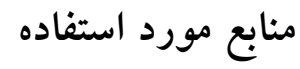

1. Abu-Qaoud, H. 2012. Improving adventitious shoot regeneration from cultured leaf explants of Petunia hybrida using thidiazuron. African Journal of Biotechnology 11: 11230-11235.

2. Abu-Qaoud, H., A.Y Abu-Rayya and S. Yaish. 2010. In vitro regeneration and somaclonal variation of Petunia hybrida. Journal of Fruit and Ornamental Plant Research 18: 71-82.

3. Abu-Rayya, A. Y. 2002. In vitro regeneration and somaclonal variation of Petunia hybrida. MSc. Thesis. An-Najah National University. Nablus.

4. Auer, C. A., J. D. Cohen, M. Laloue and T. J. Cooke. 1992. Comparison of benzyl adenine metabolism in two Petunia hybrida lines differing in shoot organogenesis. Plant Physiology 98: 1035-1041.

5. Auer, C. A., V. Motyka, A. Broezinova, M. Kaminek. 1999. Endogenous cytokinin accumulation and cytokinin oxidase activity during shoot organogenesis of Petunia hybrida. Physiologia Plantarum 105: 141-147.

6. Bhatia, R., K. P. Singh, T. Jhang and T. R. Sharma. 2009. Assessment of clonal fidelity of micropropagated gerbera plants by ISSR markers. Scientia Horticulturae 119: 208-211.

7. Bordallo, P. N., D. H. Silva, J. Maria, C. D. Cruz and E. P. Fontes. 2004. Somaclonal variation on in vitro callus culture potato cultivars. Horticultura Brasileira 22: 300-304.

8. Burbulis, N., A. Blinstrubiene and V. Jonytiene. 2015. In vitro regeneration from leaf explants of Petunia hybrida L. Propagation of Ornamental Plants 15: 47-52.

9. Christianson, M. L. and D. A. Warnick 1988. Organogenesis in vitro as a developmental process. HortScience 23: 515-519.

10. Dole, J. M. and H. F. Wilkins. 2005. Floriculture Principles and Species. Prentice- Hall, Inc. USA.

11. GriesBAch, J. R. 2007. Petunia. PP. 301-336. In: N. O. Anderson (Ed.), Flower Breeding and Genetics, Springer. USA.

12. Kag, B., V. Hegde, B. N. Sathyanarayana, R. Sharath and SH. Manchali. 2012. Direct regeneration from leaf explants of Petunia hybrida. Journal of Agricultural Science and Technology 1: 12 -17.

13. Koné, M., T. Koné, H. T. Kouakou, S. Konaté and J. S. Ochatt. 2013. Plant regeneration via direct shoot organogenesis from cotyledon explants of Bambara groundnut (Vigna subterranea L.). Biotechnology, Agronomy, Society and Environment 17: 584-592.

14. Krikorian, A. D. 1995. Hormones in tissue culture and micropropagation. PP. 774-796. In: P. J. Davies (Ed.), Plant Hormones: Physiology, Biochemistry and Molecular Biology. Dordrecht, Netherlands.

15. Lowe, K. C., M. R. Davey and J. B. Power. 1996. Plant tissue culture: past, present and future. Plant Tissue Culture and Biotechnology 2: 175-185.

16. Mendi, Y. Y., P. Curuk, E. Kocaman, C. Unek, S. Eldogan, G. Gencel and S. Cetiner. 2009. Regeneration of begonia plantlets by direct organogenesis. African Journal of Biotechnology 8: 1860-1863.

17. Motte, H., D. Vereecke, D. Geelen and S. Werbrouck. 2013. The molecular path to in vitro shoot regeneration. Biotechnology Advances 32: 107-121.

18. Nazari, F., M. Khosh-Khui and P. Azadi. 2016. A simple and efficient direct shoot organogenesis method using leafy petiole explants in Gerbera jamesonii cv. Royal Soft Pink. International Journal of Horticultural Science and Technology 3: 51-58.

19. Nazari, F., M. Khosh-Khui, P. Azadi, H. Salehi and A. Niazi. 2014. Growth regulators affected in vitro propagation of pot gerbera (Gerbera jamesonii cv. Royal Soft Pink). International Journal of Agriculture and Biosciences 3: 185-189.

20. Pollard, J. W. and J. M. Walker. 1990. Methods in Molecular Biology. Plant Cell and Tissue Culture. Humana Press, Clifton, New Jersey, USA.

21. Rao, P. S., W. Handro and H. Harada. 1973. Bud formation and embryo differentiation in in vitro cultures of Petunia. Zeitschrift für Pflanzenphysiologie 69: 87-90.

22. Renaudin, J. P., C. Tournaire and B. Teyssendier dela Serve. 1991. Quantitative analysis of protein changes during meristem initiation and bud formation in protoplast-derived Petunia hybrida callus. Physiologia Plantarum 82: 48-56. 
23. Shi, L.Y., T. J. StraBAla, G. Hagen and T. J. Guifoyle. 1994. Transgenic tobacco plants that overproduce cytokinins show increased tolerance to exogenous auxin and auxin transport inhibitors. Plant Science 100: 9-14.

24. Stehmann, J. R., A. P. Lorenz-Lemke, L. B. Freitas and J. Semir 2009. Petunia, Evolutionary, Developmental and Physiological Genetics, Springer, New York.

25. Su, Y. H., Y. B. Liu and X. S. Zhang. 2011. Auxin-cytokinin interaction regulates meristem development. Molecular Plant 4: 616-625.

26. Subotic, A., S. Jevremovic, A. Cingel and S. Milosevic. 2008. Effect of urea- type cytokinins on axillary shoot regeneration of Impatiens walleriana L. Biotechnology and Biotechnological Equipment 22: 817-819.

27. Thirukkumaran, G., V.O. Ntui, R. SherKhan, M. Mii. 2009. Thidiazuron: an efficient plant growth regulator for enhancing Agrobacterium-mediated transformation in Petunia hybrid. Plant Cell, Tissue and Organ Culture 99: 109-115.

28. Wojciechowicz, M. K. 2007. Comparison of regenerative potential of petals, stamens and pistils of five Sedum species in vitro. Biodiversity, Research and Conservation 5-8: 87-94. 


\title{
Improved Adventitious Shoot Organogenesis and Callus Production from Leaf Explants of Petunia hybrida L. by Benzyladenine (BA) and Naphthalene Acetic Acid (NAA)
}

\author{
F. Nazari ${ }^{*}$ \\ (Received: August 25-2017; Accepted: April 9-2018)
}

\begin{abstract}
Petunia (Petunia hybrida) is an ornamental plant species of high economic potential. One of the appropriate methods for propagation and breeding of petunia is tissue culture. This experiment was conducted to investigate the effects of different concentrations of benzyl adenine (BA) either alone or in combination with different concentrations of naphthalene acetic acid (NAA) on the regeneration of adventitious shoots and callus production in Petunia hybrida. For the regeneration of adventitious shoots and callus production, leaf segment explants taken from germinated seeds were cultured on MS basal media supplemented with different concentrations of BA $\left(0.1,0.4,0.8 \mathrm{mg} \mathrm{L}^{-1}\right)$ solely and/or in combinations with and NAA $\left(0,0.1,0.2\right.$ and $\left.0.4 \mathrm{mg} \mathrm{L}^{-1}\right)$. Cultures were incubated under dark conditions for two weeks and then transferred to light condition. After 20 days of keeping in the light condition, the results showed that BA and NAA had significant effect on shoot regeneration. When BA applied alone, the lowered concentrations were effective in shoot regeneration, however when used in combination with NAA, its increased concentrations were more suitable. The greatest percentage of shoot regeneration was recorded in the medium with high level of BA to NAA. The highest number and fresh weight of shoots (18 shoots per explant) were obtained in MS medium supplemented with 2 mg $\mathrm{L}^{-1}$ $\mathrm{BA}+0.4 \mathrm{mg} \mathrm{L}^{-1} \mathrm{NAA}$. The greatest shoot length $(5.1 \mathrm{~cm})$ was obtained in MS medium containing $0.5 \mathrm{mg} \mathrm{L}^{-1} \mathrm{BA}+0.2$ mg L ${ }^{-1}$ NAA. Also, the greatest callus fresh weight was observed in MS medium supplemented with $0.5 \mathrm{mg} \mathrm{L}^{-1} \mathrm{BA}+$ $0.4 \mathrm{mg} \mathrm{L}^{-1} \mathrm{NAA}$. Therefore, MS medium supplemented with $2 \mathrm{mg} \mathrm{L}^{-1} \mathrm{BA}$ combined with $0.4 \mathrm{mg} \mathrm{L}^{-1} \mathrm{NAA}$ could be suggested for direct shoot regeneration and large scale propagation of petunia from leaf explants.
\end{abstract}

Keywords: Callus, Cytokinin-to-auxin ratio, Direct shoot regeneration, Induction, Petunia

1. Assistant Professor, Department of Horticultural Science, College of Agriculture, University of Kurdistan, Sanandaj, Iran.

*: Corresponding Author, Email: f.nazari@uok.ac.ir 